\title{
THE EFFECT OF FINANCIAL LITERATURE, HUMAN RESOURCES COMPETENCE AND THE UTILIZATION OF INFORMATION TECHNOLOGY ON FINANCIAL MANAGEMENT IN MSMES IN LHOKSEUMAWE CITY
}

\author{
${ }^{1}$ Farhani, ${ }^{2}$ Hendra Raza, ${ }^{2}$ Naz'aina \\ ${ }^{1,2,3}$ Faculty of Economic and Business Universitas Malikussaleh
}

Corresponding Author: salva.safira81@gmail.com

\begin{abstract}
Micro, Small and Medium Enterprises (MSMEs) in Indonesia are one of the priorities in national economic development. MSMEs provide the largest contribution to the trade sector as much as $46.17 \%$ with a workforce distribution of $31.81 \%$ which is one of the economic drivers of the people and supporters of the Indonesian economy. In business, decision making must be rational and based on available information. This shows that the importance of the level of knowledge related to information as well as qualified human resources to make good decisions. This research design is descriptive and quantitative. This research was conducted at Micro, Small and Medium Enterprises which are active in Lhokseumawe City. Statistical analysis shows that financial literacy, human resource competence and information technology have a significant effect on the financial management of Micro, Small and Medium Enterprises in Lhokseumawe City. The results of this study provide useful information and valuable insights for MSMEs and can find out the magnitude of the role of financial literacy, human resource competence, technology and financial management in maintaining or developing a business, so as to increase innovation and be proactive in managing MSMEs so that they are able to face competition.
\end{abstract}

Keywords: Financial Management, Financial Literacy, Human Resource Competence, Information Technology, SME

\section{INTRODUCTION}

Small and Medium Enterprises (SMEs) in Indonesia are one of the priorities in national economic development. This is because these efforts are the backbone of the people's economic system, which is not only aimed at reducing the problem of inequality between opinion groups and business actors, or poverty alleviation and employment absorption. MSMEs are also one of the drivers of the people's economy in Indonesia. This is because small and medium entrepreneurs start from home industries that are managed by individuals and small business entities in the economic sector.

SMEs have an important role in the development and growth of the national economy. According to the Central Statistics Agency, the number of MSMEs in Indonesia has reached 64 million. This figure reaches $99.9 \%$ of all businesses operating in Indonesia. According to Sarwono (2015) in his remarks at the BI MSME Business Profile, he said that the 
contribution of MSMEs to the Indonesian economy is undoubted, MSMEs have a labor absorption rate of around $97 \%$ of the entire national workforce and have a contribution to gross domestic product (GDP) of around $57 \%$. Statistical data shows that in 2015, the number of MSMEs is estimated to reach 60.7 million units and most of them are micro-scale businesses (98.73 percent). MSME development is able to expand the economic base and make a significant contribution in accelerating structural change,

Empowerment of SMEs needs to be increased by the Government considering that every year the economic growth target is getting higher but it is not followed by improving the quality of SMEs. The growth of SMEs in the current of globalization and high competition makes SMEs have to face global challenges such as increasing product and service innovation, developing human resources and technology, and expanding the marketing area.

Indonesia's economic market has the potential to grow rapidly because the population will continue to grow so that the demand for supply and demand will be high. The high level of poverty and unemployment in Aceh Province is of course an irony, especially if you look at the fiscal side of Aceh Province. In terms of income, if all the regional government budgets in Aceh Province are combined, it can be seen that Aceh Province has a high regional income compared to other provinces in Sumatra. One concrete step that needs to be considered is increasing regional budget allocations to support the strengthening of micro, small and medium enterprises (MSMEs).

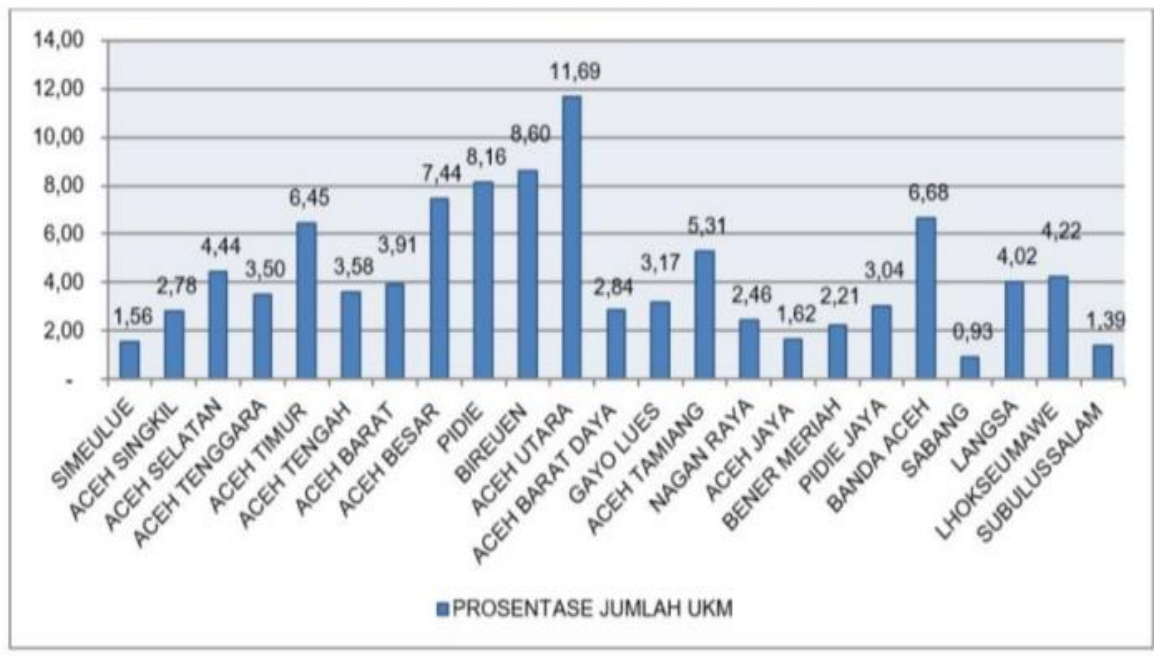

Figure 3.1. BPS Provinsi, 2019

From the data from the Department of Cooperatives and SMEs in Aceh Province, it was found that the number of MSMEs in Lhokseumawe reached 2,354 units, but from the large number of data, it was not seen that many were active and tended to fail to run their businesses. This can be seen from the picture below which shows that almost twice as many MSMEs are not active in Lhokseumawe city, so further research is needed to increase and generate business in the MSME sector.

According to Abanis et.al (2013) Financial management is all areas of management that not only involve financial resources and their use in the company but also have implications for financial decisions on investment, marketing or personnel and also the total performance of the company, so with good financial management it will have a positive 
impact on business sustainability, especially MSMEs. So if the knowledge of finance is high, it will help individuals in financial management.

According to Gavigan (2010) Financial literacy is a new reality which is the ability to adequately monitor financial resources throughout the life cycle and connect effectively with financial products and services. Financial literacy is about discernment and making effective decisions about the utilization of financial management. Meanwhile, according to Remund (2010) argues that financial literacy is the extent to which a person understands important financial concepts and has the capacity and confidence to handle personal funds appropriately, short-term decision making and solid long-term financial thinking.

Human resources are one of the useful non-financial indicators used to assess organizational performance. The popular acceptance of human resources as a performance indicator has been linked to the fact that it is the main source of competitive advantage of a company (Iveta, 2012). According to Fitz Patrick et al. (2013), by capitalizing on the competence of human resources, companies can create value and innovation that can be used to outperform competitors and improve the company's performance and financial management.

Information technology is a technology that utilizes computers as the main device to process data into useful information (Fauzi, 2008). According to Jogiyanto (2000), the use of information technology is the benefits expected by users of information technology in carrying out tasks, the measurement is based on the frequency of use and the diversity of applications that are run. Through Information Technology, financial management can be diversified, which can be distinguished from traditional financial management effectively.

\section{LITERATURE REVIEW}

\section{Micro small and Medium Enterprises}

SMEs are a collection of companies that are heterogeneous in size and nature which, when used together, will have a significant direct and indirect participation in national production, employment and job creation (Kuwayama, 2001).

\section{Financial Management}

Rivai (2013) financial management performance is a term that is generally used in part or all of the actions and activities of an organization in a period with reference to a number of standards such as projected past costs on the basis of efficiency, accountability or management accountability and the like. Griffin (2015) states that management is a process of planning, organizing, coordinating, and controlling resources to achieve goals effectively and efficiently. According to Horne (2010) defines financial management or financial management as all activities related to the acquisition, funding, and management of assets with several overarching objectives.

Bambang Riyanto (2015:31) defines financial management as the entirety of activities related to efforts to obtain funds. Kasmir (2010:16) writes that in general the functions of financial management are:

1. Forecasting and planning finances. In this case, the function of financial management is to predict conditions that will occur in the future and which are likely to have an 
impact, either directly or indirectly, on the achievement of company goals. After forecasting, plans can be drawn up, especially those related to company finances, namely customer needs and financial management.

2. Capital, investment and growth decisions. Financial management also functions to collect needed funds, both short term and long term.

3. Carry out control. This control is needed in the company because there could be financial irregularities in the company's activities. From here there is a function of financial management, namely as a control in the company's finances so that the company can still achieve its goals.

4. Relations with the capital market. Financial management is used as a liaison between the company and the capital market so that companies can obtain alternative sources of funds or capital.

\section{Financial Literacy}

Financial literacy is awareness and knowledge about financial products, financial institutions, and the concept of skills in managing finances (Xu, Lisa, and Zia, 2012). OJK stated that the vision of financial literacy is to make Indonesian people who have a high level of financial literacy able to choose and utilize financial products and services to improve their welfare. The mission of financial literacy is to provide education in the financial sector to the Indonesian people so that they can manage finances intelligently, and to improve access to information and the use of financial products and services through the development of financial literacy supporting infrastructure.

Vidovicova (2012) states that financial literacy is an understanding of financial products and concepts with the help of information and advice, as the ability to identify and understand financial risks in order to make the right financial decisions. There are three dimensions of financial literacy, namely (1) calculating skills, (2) understanding of basic finance, and (3) attitudes towards financial decisions (Carpena and Zia, 2011).

According to OJK 2013, the level of financial literacy of the Indonesian population is divided into four parts, namely:

1. Well literate, have knowledge and confidence about financial service institutions and financial service products, including features, benefits and risks, rights and obligations related to financial products and services, and have skills in using financial products and services.

2. Sufficient literate, has knowledge and belief about financial service institutions and financial products and services, including features, benefits and risks, rights and obligations related to financial products and services.

3. Less literate, only have knowledge of financial service institutions, financial products and services. 4. Not literate, do not have knowledge and confidence in financial service institutions and financial products and services, and do not have skills in using financial products and services. 


\section{Human Resources Competence}

Human resource competence includes its capacity, namely the ability of a person or individual, an organization (institutional), or a system to carry out its functions or authority to achieve its goals effectively and efficiently (Azhar, 2007). Capacity should be seen as the ability to achieve performance, to produce outputs and outcomes. According to Tjiptoherijanto (2001) to assess the capacity and competence of human resources in carrying out a function, it can be seen from the level of responsibility and competence of these resources.

Competence is a characteristic of someone who has the skills, knowledge, and ability to carry out a job (Havesi, 2005). Competence can be seen from managerial competence, practical competence, procedural competence, cooperation and discipline at work.

1. Managerial competence is the ability of SME managers to organize, coordinate and move subordinates towards achieving the goals that have been determined by the organization.

2. Practical competence is the ability of UKM managers to carry out all operational activities in a real and direct manner in SMEs based on existing theories.

3. Procedural competence is the ability of UKM managers to comply with every procedure that exists within SMEs to support the work. The procedure for running this business has been determined by the company based on the SOP that has been set in accordance with the company's objectives.

\section{Information Technology}

Information technology is the study or electronic computer equipment to store, analyze, and distribute all information (Oxford dictionary, 1995), meanwhile Lucas (2000) mentions information technology is all forms of technology applied to process and transmit information in electronic form. Information technology can be broadly defined as a technology used to obtain, process, process, compile, store and manipulate data in various ways to produce quality information, namely timely information used for various purposes (personal, private, government) to support decision making (Zaky Alkazar Nasution, 2011).

The financial management of a company can use technology to complete complex work through the intervention of Information Technology to achieve breakthrough critical and challenging points in the field of industrial technology. In addition, after the combination of enterprise information data and Information Technology can form effective communication between corporate managers and investors can be achieved through the Internet sharing platform, and decision-making information can be implemented by accessing shared information in the system on the website, to realize effective economic communication between companies and customers.

\section{CONCEPTUAL FRAMEWORK AND HYPOTHESES}

The conceptual framework is a form of thinking concept that is used as an approach in problem solving. In the conceptual framework, the research uses a scientific approach and shows the relationship between variables as a process to analyze. The conceptual framework consists of the flow or stages of the systematic thinking process starting from the background 
of the research, problem formulation, problem analysis and suggestions or solutions from alternatives to existing problems.

\section{The Effect of Financial Literacy on Financial Management}

In research conducted by Andrew (2014) in Yushita (2017:23) which states that there is a significant relationship between financial knowledge and financial behavior where the higher a person's financial knowledge, the more wise they tend to be in managing their finances. By having financial capabilities, MSMEs are not only proficient in financial management but can also assist MSMEs in making decisions related to their business. Therefore, the researchers tried to re-examine the relationship between the influence of financial literacy on financial management.

\section{Competence of Human Resources on Financial Management}

In research conducted by Katou (2009) notes that there is a positive relationship between HR management policies and company performance on financial management. Therefore, the researchers tried to re-examine the relationship between the influence of human resource compensation on financial management.

\section{Effect of Utilization of Information Technology on Financial Management}

The relationship between IT usage and firm performance has been extensively researched over the past few years. The results show a significant correlation between IT and firm performance (Alphar and Kim, 2000).Therefore, the researchers tried to re-examine the relationship between the influence of the use of information technology on financial management.

Based on the description above, the conceptual framework that can be built in this research is as follows:

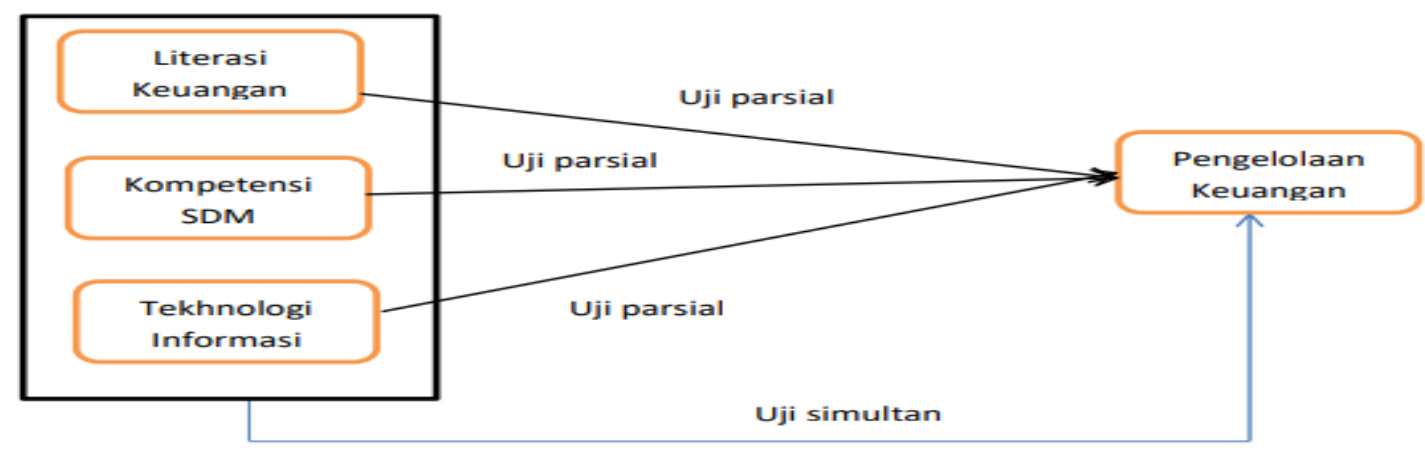

Figure 3.2. conceptual framework

\section{RESEARCH METHODS}

This research was conducted on Micro, Small and Medium Enterprises in Lhokseumawe City with the variables used as objects were financial literacy, human resource competence, information technology and financial management. The research locations are 
all sub-districts in the Lhokseumawe City area that have Micro, Small and Medium Enterprises that are active in their business activities.

\section{Data collection technique}

The data collection technique is through a method using questionnaires distributed to respondents according to the criteria in Lhokseumawe City by giving questionnaires directly. The respondents were asked to complete the questionnaire provided. The questionnaire given contains statements for the variables of financial literacy, human resource competence, information technology and financial management.

\section{Data analysis technique Validity test}

The validity test aims to see whether the questionnaire used to measure the research variables is valid or not. The questionnaire can be said to be valid if the questions on the questionnaire are able to reveal something that is measured by the questionnaire.

In this study, the validity test was carried out by looking at the correlated item total correlation, the correlated item total correlation above 0.05 was highly recommended.

\section{Reliability Test}

The reliability test of the instrument used in the study to obtain information used can be trusted as a data collection tool and is able to reveal actual information in the field. This test is carried out using the Cronbach alpha method, namely an instrument is said to be reliable if the coefficient value is 0.6 or greater than 0.6 .

\section{Classic assumption test Normality test}

The normality test was conducted to see whether the regression model, the dependent variable and the independent variable had a normal distribution or not. The data will be analyzed using Komogorov-Smirnov analysis, Normal Probability Plot analysis (Normal PP Plot) and Histogram Graph analysis. When the data were analyzed using the KomogorovSmirnov analysis, the data were considered normal if the significance test value was greater than 0.05 . On the other hand, if the result of the significance test is less than 0.05 , then the data is not normally distributed.

\section{Multicollinearity Test}

The multicollinearity test was used to determine whether there was a strong correlation between the independent variables included in the model formation. To detect whether the linear regression model has multicollinearity, it can be checked using the Variance Inflation Factor (VIF) for each independent variable, that is, if the independent variable has a VIF value that does not exceed 4 or 5 , it means that there is no multicollinearity (Ikhsan et al., 2014). 


\section{Heteroscedasticity Test}

In the multiple regression equation, it is necessary to test whether or not the variance of the residuals from one observation is equal to another. If the residuals have the same variance, it is called homoscedasticity, and if the variance is not the same/different, it is called heteroscedasticity. A good regression equation is if there is no heteroscedasticity (Sunyoto, 2011:82).

How to analyze the assumption of heteroscedasticity by looking at the scatterplot graph, where:

a. Homoscedasticity occurs if in the scatterplot the points resulting from data processing between ZPRED and SRESID spread below and above the origin point (number 0).

b. Heteroscedasticity occurs if the scatterplot points have a regular pattern, either narrowing, widening or wavy waves.

\section{Multiple Linear Regression Analysis}

Multiple regression analysis is used by researchers, if the researcher intends to predict how the condition (increase and decrease) of the dependent variable (criteria), if two or more independent variables as predictor factors are manipulated (increase in value). So, multiple regression analysis will be carried out if the number of independent variables is at least 2 (two) (Sugiyono, 2010). The regression analysis model formula used is as follows:

$$
\mathrm{Y}=\mathbf{0}+\mathbf{1 X 1}+\mathbf{2 X 2}+3 \mathrm{X3}+\mathrm{e}
$$

The results of the regression analysis are in the form of coefficients for each independent variable. The regression coefficient shows the magnitude of the constants and parameters of each independent variable in the equation.

\section{Research Hypothesis Testing \\ Partial Test}

This test is carried out to determine whether or not each regression coefficient value $(\mathrm{X} 1, \mathrm{X} 2$, and $\mathrm{X} 3$ ) is significant or insignificant on the dependent variable (Y) (Sunyoto, 2011: 13).

\section{Simultaneous Significant Test}

This test involves the three variables on the dependent variable in testing the presence or absence of a significant effect simultaneously/together. Simultaneous testing uses the F distribution, which compares the calculated F (F ratio) and F table (Sunyoto, 2011).

\section{Correlation Coefficient (r) and Determination (R2)}

The correlation coefficient aims to determine whether or not there is a strong relationship between variable $\mathrm{X}$ and variable $\mathrm{Y}$ which is linear. The value of the correlation coefficient is at least -1 , so that if the correlation coefficient is expressed by the formula $r=1$, it indicates that the relationship between the variables $\mathrm{X}$ and $\mathrm{Y}$ is positive and perfect, while if it is negative, it indicates the relationship between the variables $\mathrm{X}$ and $\mathrm{Y}$ is perfect but has a negative value. However, if it is found that the value of $r$ is 0 (zero), it indicates a weak relationship or no relationship at all between the $\mathrm{X}$ variable and the $\mathrm{Y}$ variable. 
The coefficient of determination (R2) is used to measure how far the ability of a model to explain a variation of the dependent variable. The value of the coefficient of determination is between zero and one. A small value of the coefficient of determination indicates that the ability of the independent variable to explain the dependent variable is very limited, as well as if the value of the coefficient of determination is getting closer to one, it shows the strength of the independent variable in providing the information needed to predict the variation of the dependent variable (Ghozali, 2011).

\section{ANALYSIS RESULTS Validity}

\begin{tabular}{|c|c|c|c|}
\hline \multicolumn{4}{|c|}{ Variabel Literasi Keuangan (X1) } \\
\hline Pernyataan & $\mathbf{r}_{\text {hitung }}$ & $\mathbf{r}_{\text {tabel }}$ & Validitas \\
\hline 1 & 0,824 & 0,196 & Valid \\
\hline 2 & 0,367 & 0,196 & Valid \\
\hline 3 & 0,757 & 0,196 & Valid \\
\hline 4 & 0,846 & 0,196 & Valid \\
\hline 5 & 0,800 & 0,196 & Valid \\
\hline 6 & 0,663 & 0,196 & Valid \\
\hline 7 & 0,434 & 0,196 & Valid \\
\hline 8 & 0,357 & 0,196 & Valid \\
\hline \multicolumn{4}{|c|}{ Variabel Kompetensi Sumber Daya Manusia (X2) } \\
\hline Pernyataan & $\mathbf{r}_{\text {hitung }}$ & $\mathbf{r}_{\text {tabel }}$ & Validitas \\
\hline 1 & 0,815 & 0,196 & Valid \\
\hline 2 & 0,765 & 0,196 & Valid \\
\hline 3 & 0,870 & 0,196 & Valid \\
\hline 4 & 0,579 & 0,196 & Valid \\
\hline 5 & 0,713 & 0,196 & Valid \\
\hline 6 & 0,785 & 0,196 & Valid \\
\hline 7 & 0,666 & 0,196 & Valid \\
\hline 8 & 0,665 & 0,196 & Valid \\
\hline \multicolumn{4}{|c|}{ Variabel Tekhnologi Informasi (X3) } \\
\hline Pernyataan & $\mathbf{r}_{\text {hitung }}$ & $\mathbf{r}_{\text {tabel }}$ & Validitas \\
\hline 1 & 0,568 & 0,196 & Valid \\
\hline 2 & 0,862 & 0,196 & Valid \\
\hline 3 & 0,849 & 0,196 & Valid \\
\hline 4 & 0,925 & 0,196 & Valid \\
\hline 5 & 0,630 & 0,196 & Valid \\
\hline 6 & 0,875 & 0,196 & Valid \\
\hline \multicolumn{4}{|c|}{ Variabel Pengelolaan Keuangan $(Y)$} \\
\hline Pernyataan & $\mathbf{r}_{\text {hitung }}$ & $\mathbf{r}_{\text {tabel }}$ & Validitas \\
\hline 1 & 0,796 & 0,196 & Valid \\
\hline 2 & 0,719 & 0,196 & Valid \\
\hline 3 & 0,842 & 0,196 & Valid \\
\hline 4 & 0,420 & 0,196 & Valid \\
\hline 5 & 0,656 & 0,196 & Valid \\
\hline 6 & 0,611 & 0,196 & Valid \\
\hline 7 & 0,551 & 0,196 & Valid \\
\hline 8 & 0,553 & 0,196 & Valid \\
\hline
\end{tabular}


The results of the SPSS calculation obtained the value of corrected item total correlation shown from the table on the value of $r$ table is greater than 0.1666 , then the question item is said to be valid.so that it is suitable for use in this study and further research.

\section{Reliability}

\begin{tabular}{lccc}
\hline \multicolumn{1}{c}{ Variabel } & $\begin{array}{c}\text { Chronbach } \\
\text { alpha }\end{array}$ & Konstanta & Reliabilitas \\
\hline Literasi Keuangan(X1) & 0,807 & 0,6 & Reliabel \\
$\begin{array}{l}\text { Kompetensi Sumber Daya Manusia } \\
\text { (X2) }\end{array}$ & 0,877 & 0,6 & Reliabel \\
Tekhnologi Informasi (X3) & 0,876 & 0,6 & Reliabel \\
Pengelolaan Keuangan (Y) & 0,796 & 0,6 & Reliabel \\
\hline
\end{tabular}

Source: Processed Data, 2021

The results of the reliability test using Cronbach Alpha, all research variables are reliable/reliable because Cronbach Alpha is greater than 0.6, so the results of this study indicate that the measurement tool in this study has met the reliability test (reliable and can be used as a measuring instrument).

\section{Normality test}

From the results of the normality test, it can be seen that the Asymp value. Sig. (2tailed) of $0.200>0.05$, it can be concluded that the data is normally distributed. Because the data are normally distributed, one condition for the One-Way ANOVA test has been met.

\section{Multicollinearity Test}

From the results of the multicollinearity test It is known that the tolerance value of each independent variable in the study is $>0.10$ and the VIF value is $<10$. Based on these results, it can be concluded that all independent variables consist of Financial Literacy, Human Resource Competence and Information Technology, there are no symptoms of multicollinearity.

\section{Heteroscedasticity Test}

The results of the Heteroscedasticity test are known to have sig values. (2 tailed) the Financial Literacy variable was $0.108>0.05$, the Human Resources Competency variable was $0.627>0.05$ and the Information Technology variable was $0.082>0.05$. From these results it can be concluded that the model in this test does not occur heteroscedasticity or homoscedasticity.

\section{Correlation Analysis}

Based on the results of the correlation analysis, it was found that the correlation values of Financial Literacy, Human Resource Competence, and Information Technology have a positive relationship with Financial Management. Each is $0.712 ; 0.620 ; 0.737$ and has a value greater than rtable of 0.256 , with a significant value of 0.01 at the $1 \%$ level. Shows 
that by correlation there is a positive relationship between Financial Literacy, Human Resource Competence, and Information Technology. In other words, the increase in Financial Literacy, Human Resource Competence, and Information Technology will also increase the understanding of MSMEs related to Financial Management.

Furthermore, the value of sig is known. ( 2 tailed) between Financial Literacy and Financial Management is $0.000<0.01$, which indicates that there is a significant correlation between the Financial Literacy variable and the Financial Management variable, furthermore, the sig value is known. (2 tailed) between Human Resource Competence and Financial Management is $0.000<0.01$, which indicates that there is a significant correlation between the Human Resources Competence variable and the Financial Management variable, lastly, the sig value is known. (2 tailed) between Information Technology and Financial Management is $0.000<0.01$, which indicates that there is a significant correlation between Information Technology and Financial Management variables.

\section{Multiple Linear Regression Results}

$$
\mathrm{Y}=\mathbf{5 . 3 6 8}+\mathbf{0 . 3 1 0 X 1}+\mathbf{0 . 1 9 3 X} 2+0.529 \mathrm{X} 3+\mathrm{e}
$$

The results of linear regression analysis, the effect of understanding on Financial Literacy on the ability to manage MSME finances is 0.310 . So, it can be concluded that if the understanding of Financial Literacy is improved, then one's ability to manage finances in MSMEs will also increase by 0.310 .

Furthermore, the influence of competence possessed by human resources on the ability to manage MSME finances is 0.193 . So, it can be concluded that if the competence of human resources in MSMEs is increased, then a person's ability to manage finances will increase by 0.193 .

Furthermore, the influence of information technology on one's ability to manage MSME finances is 0.529 . So, it can be concluded that if the ability of information technology in MSMEs is improved, then one's ability to manage finances will increase by 0.529 .

\section{Coefficient of Determination Results}

The correlation coefficient value is 0.794 or $79.4 \%$. Which indicates the magnitude of the influence given by the variables of Financial Literacy, Competence of Human Resources and Information Technology on the Financial Management of MSMEs in Lhokseumawe City. And the value of $\mathrm{R}$ square is 0.631 or $63.1 \%$, so it can be concluded that the effect of Financial Literacy, Human Resource Competence and Information Technology on MSME Financial Management in Lhokseumawe City is $63.1 \%$, the remaining $36.9 \%$ is influenced by other factors that not included in this study. 


\section{Hypothesis Test Results}

\begin{tabular}{llccccc}
\hline \multicolumn{7}{c}{ Coefficients $^{\mathbf{a}}$} \\
\hline \multirow{7}{*}{ Unstandardized } & Standardized \\
Codel & & Coefficients & Coefficients & \\
& & B & Std. Error & Beta & t & Sig. \\
& (Constant) & 5,368 & 2,030 & & 2,645 &, 010 \\
LiterasiKeuangan &, 310 &, 133 &, 249 & 2,338 &, 021 \\
KompetensiSDM &, 193 &, 056 &, 263 & 3,434 &, 001 \\
T.Informasi &, 529 &, 140 &, 395 & 3,765 &, 000 \\
\hline
\end{tabular}

Dependent Variable: PengelolaanKeuangan

Source: Processed Data, 2021

Based on the test results in the table above, the test results for each hypothesis are as follows:

a. Test results It is known from the table above that the $t$-count value is 2.338 and a significant value is 0.021 . By looking at the partial test criteria, it is known that the $t$ table value is 1.66 with the formula (NK-1). So the value of $t$ count is greater than $t$ table $2,338>1.66$ and sig value $0.021<0.05$. It can be concluded that there is a significant influence between Financial Literacy variables on MSME Financial Management.

b. The test results from the table above have a t-count value of 3.434 and a significant value of 0.001 . By looking at the partial test criteria, it is known that the table value is 1.66 with the formula (NK-1). So that the value of $t$ count is greater than t table $3.434>1.66$ and the value of sig is $0.001<0.05$. It can be concluded that there is a significant influence between the variables of Human Resource Competence on MSME Financial Management.

c. Test results It is known from the table above that the t-count value is 3.765 and the significant value is 0.000 . By looking at the partial test criteria, it is known that the $t$ table value is 1.66 with the formula (NK-1). So that the value of $t$ count is greater than $t$ table $3.765>1.66$ and the value of sig $0.000<0.05$. It can be concluded that there is a significant influence between Information Technology variables on MSME Financial Management. 


\section{One-Way ANOVA Test Results \\ Financial Literacy ANOVA Results}

\begin{tabular}{lcrrrrr}
\hline \multicolumn{7}{c}{ ANOVA } \\
\hline Literasi Keuangan & \multicolumn{7}{c}{} \\
\hline & $\begin{array}{l}\text { Sum of } \\
\text { Squares }\end{array}$ & df & & Mean Square & F & Sig. \\
\hline Between & 965,772 & & 2 & 482,886 & 98,447 &, 000 \\
Groups & & & & & & \\
Within Groups & 475,788 & 97 & 4,905 & & \\
Total & 1441,560 & 99 & & & \\
\hline
\end{tabular}

Source: Processed Data, 2021

Based on the table above, it is known that the sig value is $0.000<0.05$, which indicates that there is a significant difference in the Financial Literacy variable when analyzed with the type of micro, small and medium business in MSMEs in Lhokseumawe City. However, the results of the ANOVA are comprehensive, namely together. To find out whether or not there are significant differences between groups of business types, the Post Hoc Test is carried out

ANOVA Results of Human Resources Competence

\section{ANOVA}

\begin{tabular}{|c|c|c|c|c|c|}
\hline \multicolumn{6}{|c|}{ Kompetensi SDM } \\
\hline & Sum of & & & & \\
\hline & Squares & df & Mean Square & $\mathrm{F}$ & Sig. \\
\hline Between & 1627,520 & 2 & 813,760 & 31,212 & ,000 \\
\hline \multicolumn{6}{|l|}{ Groups } \\
\hline Within Groups & 2528,990 & 97 & 26,072 & & \\
\hline Total & 4156,510 & 99 & & & \\
\hline
\end{tabular}

Source: Processed Data, 2021

Based on the table above, it is known that the sig value is $0.000<0.05$, which indicates that there is a significant difference in the Human Resource Competency variable when analyzed with the type of micro, small and medium business in MSMEs in Lhokseumawe City. 


\section{Information Technology ANOVA Results}

\begin{tabular}{|c|c|c|c|c|c|}
\hline \multicolumn{6}{|c|}{ ANOVA } \\
\hline T.Informasi & & & & & \\
\hline & $\begin{array}{l}\text { Sum of } \\
\text { Squares }\end{array}$ & $\mathrm{df}$ & Mean Square & $\mathrm{F}$ & Sig. \\
\hline Between & 850,078 & 2 & 425,039 & 102,429 & ,000 \\
\hline \multicolumn{6}{|l|}{ Groups } \\
\hline Within Groups & 402,512 & 97 & 4,150 & & \\
\hline Total & 1252,590 & 99 & & & \\
\hline
\end{tabular}

Source: Processed Data, 2021

Based on table 5.16, it is known that the sig value is $0.000<0.05$, which indicates that there is a significant difference in the Information Technology variable when analyzed with the type of micro, small and medium businesses in MSMEs in Lhokseumawe City.

\section{Financial Management ANOVA Results}

\begin{tabular}{|c|c|c|c|c|c|}
\hline \multicolumn{6}{|c|}{ ANOVA } \\
\hline \multicolumn{6}{|c|}{ PengelolaanKeuangan } \\
\hline & Sum of & & & & \\
\hline & Squares & $\mathrm{df}$ & Mean Square & $\mathrm{F}$ & Sig. \\
\hline Between & 1672,276 & 2 & 836,138 & 141,123 & ,000 \\
\hline \multicolumn{6}{|l|}{ Groups } \\
\hline Within Groups & 574,714 & 97 & 5,925 & & \\
\hline Total & 2246,990 & 99 & & & \\
\hline
\end{tabular}

Source: Processed Data, 2021

Based on the table above, it is known that the sig value is $0.000<0.05$, which indicates that there is a significant difference in the Financial Management variable when analyzed with the type of micro, small and medium business in MSMEs in Lhokseumawe City. 


\section{Discussion}

\section{The Influence of Financial Literacy on Financial Management}

The results of the direct effect test show that $\mathrm{H} 1$ is accepted. This means that improving financial management requires good financial literacy. This implies that with good financial literacy, it is hoped that MSMEs will be able to make the right management and financial decisions to improve performance and business sustainability.

2. Understanding of Financial Literacy is Measured through Micro, Small and Medium Business Types

The results of the direct effect test show that $\mathrm{H} 2$ is rejected. This matterThis means that there is no significant difference between the two types of business. The conclusion isthe understanding of medium-sized businesses regarding the concept of financial literacy is better than the understanding of micro and small business actors.

\section{The Influence of Resource Competence on Financial Management}

The results of the direct effect test show that $\mathrm{H} 3$ is accepted. It means, The ability of human resources owned by MSMEs in Lhokseumawe City is relatively low in managing their business finances. Another thing that also has an impact on professional financial management in every business is the use of money that is right on target so that it does not become an excessive expenditure or even becomes an idealism of a relatively high business manager but is excessive in being careful in the use of money because it adheres to the attitude of love of money.

\section{Human Resource Competence is Measured through Micro, Small and Medium Business Types}

The results of the direct effect test show that $\mathrm{H} 4$ is rejected. It means, there is no significant difference between the two types of business. So it can be concluded that the inability of Human Resources owned by Micro and Small business actors is related to managing MSME finances.

\section{The Effect of Information Technology on Financial Management}

The results of the direct effect test show that H5 is accepted. It means, that the ability of Lhokseumawe City MSME actors in managing electronic-based businesses is relatively low in managing their business, especially managing their business finances. So that business actors in this case must be given training related to how to manage an electronicbased business.

\section{Information Technology Application Capability Measured Through Micro, Small and Medium Business Types}

The results of the direct effect test show that $\mathrm{H} 4$ is rejected. It means, there is no significant difference between the two types of business. So it can be concluded that the inability of Micro and Small business actors in applying Information Technology to manage their businesses. However, in contrast to the Medium business type, the ability of Medium business actors to apply their Information Technology can be said to be good in managing their business. 


\section{The ability to manage finances is measured through the type of micro, small and medium business}

The results of the direct effect test show that $\mathrm{H} 4$ is rejected. It means, that there is no significant difference between the two types of business. So it can be concluded that the inability of micro and small business actors in managing their business finances.

\section{CONCLUSION}

The conclusion of this study with the title PInfluence of Financial Literacy, Human Resource Competence and Utilization of Information Technology on Financial Management in Lhokseumawe City MSMEs.

In more detail the conclusions in this study are:

1. Financial literacy has a significant effect on the financial management of Micro, Small and Medium Enterprises in Lhokseumawe City. This proves that understanding financial literacy is a factor that can improve the ability to manage finances for Micro, Small and Medium Enterprises (MSMEs).

2. Human resource competence has a significant effect on the financial management of Micro, Small and Medium Enterprises in Lhokseumawe City. This proves that the ability of human resources is a factor that can improve the ability to manage the finances of Micro, Small and Medium Enterprises (MSMEs).

3. Information technology has a significant effect on the financial management of Micro, Small and Medium Enterprises in Lhokseumawe City. This proves that the ability to apply information technology is a factor that can improve the ability to manage the finances of Micro, Small and Medium Enterprises (MSMEs).

\section{REFERENCES}

Fuadi, A. F. H. H., Ilham, R. N., \& Saputra, J. Investigating the Effect of Micro Waqf Bank Sector Expansion on Poverty Alleviation: An Evidence from Indonesia Rural Communities.

Gavigan, K. 2010. Show me the money resources: Financial literacy for 21 st century learners. Library Media Connection 28(5):24-27.

Ilham, R. N., Sinurat, M., Saputra, J., \& Putri, D. E. Does Social media affect Banking Industry Financial Performance in Indonesia.

Remund, David L. (2010). Financial Literacy Explicated: The Case for a Clearer Definition in an Increasingly Complex Economy. The Journal of Consumer Affairs, 44(2), 276295.

Kuwayama, M. (2001). E-Commerce and export promotion policies for small and mediumsized enterprises: East Asian and Latin American experiences (Vol. 13). United Nations Publications. 
ST. Maryam, Rachma Atamimi, Eko Sumartono, Dwi Orbaningsih, Riinawati (2020) GLOBAL FINANCIAL CRISIS MANAGEMENT BY HUMAN RESOURCE MANAGEMENT. Journal of Critical Reviews, 7 (1), 287-290. doi: $10.31838 /$ jcr.07.01.53

Rivai, Veithzal; Sofyan Basir; Sarwono Sudarto; Arifiandy Gem Veithzal. 2013. Commercial Bank Management: Banking Management from Theory to Practice, edition 1, printing 1. Jakarta: Rajawali Pers.

Griffin, (2012). Organizational Commitment. Translation, Jakarta : PT. Erlangga.

Horne, James C. Van and John M. Wachowicz. (2012). Financial Management Principles. Edition 13. Salemba Empat, Jakarta.

Xu, Lisa., and Bilal Zia. 2012. Financial Literacy around the World - An Overview of the Evidence with Practical Suggestions for the Way Forward. The World Bank: Finance and Private Sector Development.

Vidovicova, Lucie, "Aging in european" Societes International Perspectives on Aging, vol. 6, no. 1, p. 191, 2012.

Carpena, Fenella., Cole, Shawn., Shapiro, Jeremy., \& Zia, Bilal. (2011). Unpacking the Causal Chain of Financial Literacy. Policy Research Working Paper 5798.

Lucas, HC (1999). Information Technology and the Productivity Paradox. Oxford University Press: New York.

Alpar P, Kim M. A microeconomic approach to the measurement of information technology value. Journal of Management Information Systems. 1990; 7(2):55-69. 